UOT 541.183

\title{
REMOVAL OF Fe(III) IONS USING PHOSPHORUS-CONTAINING SORBENT ON THE BASIS OF BUTADIENE-STYRENE RUBBER
}

\author{
E.S.Karimova, A.A.Azizov, R.M.Alosmanov \\ Baku State University \\ afinabdu@rambler.ru
}

Received 28.02.2019

\begin{abstract}
Phosphorus-containing polymeric sorbent on the basis butadiene-styrene rubber was used to remove $\mathrm{Fe}(\mathrm{III})$ ions from water. The research was carried out to study the sorption characteristics by determining the effects of various parameters, such as the $\mathrm{pH}$ of the solution, the initial concentration of metal ions, the sorbent mass, contact time, and temperature.
\end{abstract}

Keywords: removal, polymer sorbent, sorption, iron.

\section{Introduction}

Heavy metal compounds are one of the most toxic substances. Contained in drinking water ions of heavy metals, getting into animal organisms, block enzyme systems, what leads to a sharp disruption of their life. The sources of heavy metals entering the water are emissions from industrial enterprises, as well as corrosive water supply equipment. There are various ways to purify water from heavy metal compounds. So in one of the promising methods of water purification from copper(II) ions is ion exchange [1]. For the purification of chromium-containing effluents, technologies using high-efficiency redox sorbent of iron(II) hydroxide are used [2]. Among heavy metals in drinking water, iron is usually at its maximum concentrations, which has both natural and man-made sources. The most common methods of deironing today are cleaning methods using sand and anthracite backfill. However, these fillings do not provide the required level of water purification, and dangerous to human health toxic aromatic organic compounds can be released from the anthracite backfill. In addition, filters with sand and anthracite backfill are quite cumbersome because of the low absorptive capacity of the fillers [3].

Compared with other methods, sorption is superior in design simplicity, initial cost, ease of operation and insensitivity to toxic substances. This method uses a large number of suitable sorbents, such as activated carbon [2], inexpensive adsorbents (natural, industrial, as well as synthetic materials, wastes) [4] and polymeric materials (sorbent and resins) [3].
The aim of this work was to study the effectiveness of phosphorus-containing sorbent based on butadiene-styrene rubber, used to remove Fe(III) ions from aqueous solutions. The method of synthesis of phosphorus-containing sorbent by chemical modification (oxidative chlorophosphorylation reaction) of industrial polymer butadiene-styrene rubber was developed by our scientists and described earlier [5, 6]. It was found that this reaction proceeds using readily available commercial reagents under mild conditions and using simple equipment. This paper presents the influence of various parameters, such as the concentration of the initial $\mathrm{Fe}(\mathrm{III})$ solution, the $\mathrm{pH}$ of the solution, the sorbent mass, contact time and temperature.

\section{Experimental part}

The modified butadiene-styrene rubber was used as the sorbent for studying the sorption behavior of $\mathrm{Fe}(\mathrm{III})$ ions in aqueous solution. Phosphorus-containing sorbent was synthesized on the basis of butadiene-styrene rubber using $\mathrm{PCl}_{3}, \mathrm{CCl}_{4}, \mathrm{H}_{2} \mathrm{SO}_{4}$ and $\mathrm{O}_{2}$ [6]. Butadiene-styrene rubber was purchased from the Voronezh Synthetic Rubber Manufactory (Russia). $\mathrm{PCl}_{3}, \mathrm{CCl}_{4}$, $\mathrm{H}_{2} \mathrm{SO}_{4}$ were purchased from Vecton (Russia) and used without further purification.

The ferric chloride working solution was prepared by dissolving the $\mathrm{FeCl}_{3} \cdot 6 \mathrm{H}_{2} \mathrm{O}$ sample in an appropriate amount of distilled water. The $\mathrm{pH}$ value in the solution was established using an acetate-ammonia buffer solution.

The concentrations of $\mathrm{FeCl}_{3} \cdot 6 \mathrm{H}_{2} \mathrm{O}$ after sorption were determined using a photometric 
colorimeter with an optical density determination at a wavelength of $490 \mathrm{~nm}$.

Preliminary experiments began with the aim of studying the effect of the $\mathrm{pH}$ of the solution, sorbent mass, contact time, temperature and the initial concentration of metal ions on the sorption of $\mathrm{Fe}$ (III) ions by a phosphoruscontaining sorbent. Precisely weighed amount of sorbent $(0.05 \mathrm{~g})$ was placed in flasks and filled with $\mathrm{FeCl}_{3} \cdot 6 \mathrm{H}_{2} \mathrm{O}$ solutions of different initial concentrations. In this case, the initial concentrations of the samples were changed in the range from $0.9 \cdot 10^{-3}$ to $2.6 \cdot 10^{-3} \mathrm{M}$. When studying the effect of the sorbent mass on sorption, the mass of the sorbent was varied in the range from 0.01 to $0.1 \mathrm{~g}$. The solutions of iron(III) chloride with a $\mathrm{pH}$ of 1 to 11 were used in order to determine the effect of the $\mathrm{pH}$ of the solution. A study of the dependence of the sorption on contact time was carried out using $0.3 \mathrm{~g}$ of sorbent and $90 \mathrm{ml}$ of $\mathrm{FeCl}_{3} \cdot 6 \mathrm{H}_{2} \mathrm{O}$ solution with $1.5 \cdot 10^{-3} \mathrm{M}$ concentration and changing the contact time in a range from 3 to $65 \mathrm{~min}$, and temperatures of 25,35 and $50^{\circ} \mathrm{C}$. In recent experiments, the sample was taken every 3-5 min and analyzed on a spectrophotometer. The sorption capacity $(\mathrm{SC}, \mathrm{mg} / \mathrm{g}$ ) and the degree of adsorption (\%) were calculated using equations (1) and (2)

$$
\begin{gathered}
\mathrm{SC}=\left(C_{\mathrm{o}}-C_{\mathrm{e}}\right) \frac{\mathrm{V}}{\mathrm{m}}, \\
R=\frac{100\left(C_{0}-C_{\mathrm{e}}\right)}{C_{0}},
\end{gathered}
$$

where $C_{0}$ and $C_{\mathrm{e}}$ are the initial and equilibrium concentrations of $\mathrm{Fe}(\mathrm{III})$ ions in the solution, respectively $(\mathrm{mg} / \mathrm{ml}), V$ is the volume of the solution $(\mathrm{ml})$, and $\mathrm{m}$ is the sorbent mass $(\mathrm{g})$.

The results showed that $1.5 \cdot 10^{-3} \mathrm{M}$ $\mathrm{FeCl}_{3} \cdot 6 \mathrm{H}_{2} \mathrm{O}, 0.05 \mathrm{~g}$ adsorbent was used as the optimal concentration for studying the effect of $\mathrm{pH}$ on the sorption of $\mathrm{Fe}$ (III) ions. Based on the results obtained, adsorption isotherms are determined.

The results were statistically processed using standard methods [7, 8]. The average error of the experiment was estimated to be less than $4 \%$.

\section{Results and discussion}

Description of the reaction and characteristics of the phosphorus-containing polymeric sorbent.

Synthesis of phosphorus-containing sorbent was described in earlier works [6]. It should be emphasized that during the polymer modification reaction, a crosslinking process occurs between macromolecular chains. As a result, cross-linked products with various functional groups, such as: $-\mathrm{P}(\mathrm{O}) \mathrm{Cl}_{2}$ (phosphonium dichloride) and - $\mathrm{OP}(\mathrm{O}) \mathrm{Cl}_{2}$ (phosphorus dichloride), which were converted by the hydrolysis reaction to phosphonate $\left(-\mathrm{P}(\mathrm{O})(\mathrm{OH})_{2}\right)$ and phosphate $\left(-\mathrm{OP}(\mathrm{O})(\mathrm{OH})_{2}\right)$ groups, respectively. The synthesized phosphorus-containing sorbent on the basis of butadiene-styrene rubber is a dark brown powder with a cross-linked structure, insoluble in organic solvents, mineral acids and alkalis $[9,10]$.

\section{$U V$-spectroscopy}

Figure 1 shows the ultraviolet spectra of the phosphorus-containing polymeric sorbent on the basis of butadiene-styrene rubber before and after adsorption.
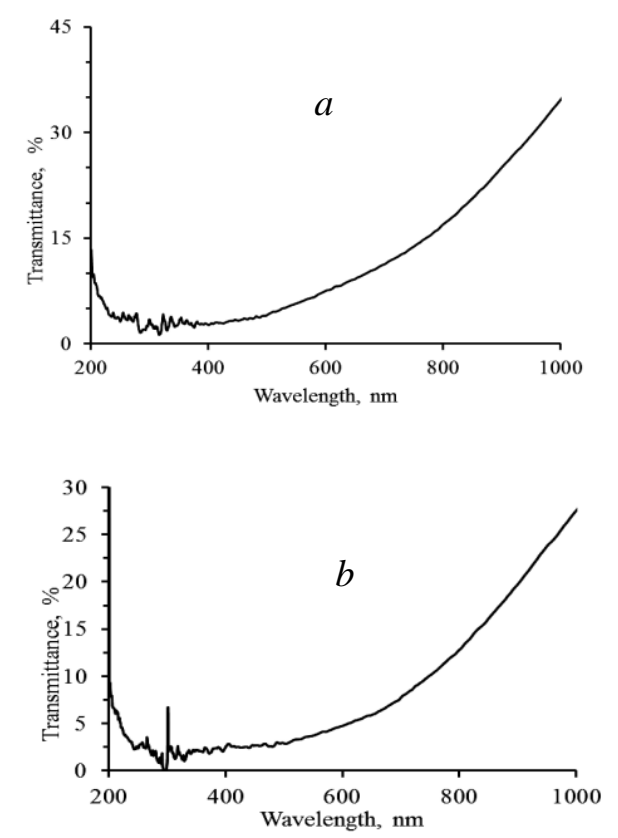

Fig. 1. UV-spectra or the phosphorus-containing polymeric sorbent on the basis of butadienestyrene rubber: $a$ - before and $b$ - after adsorption or iron. 
The $\mathrm{pH}$ of the solution is one of the most important experimental factors, which determines the sorption selectivity during sorption on sorbents. The $\mathrm{pH}$ value determines the specific surface charge of the sorbent and the ionic dissociation of $\mathrm{Fe}(\mathrm{III})$ ions in the solution [11]. This physico-chemical parameter, because of its effect on the degree of protonation and the dissociation of functional groups, is very important for a phosphorus-containing sorbent on the basis of polymer [10].

Table 1 shows the results of investigating the effect of the solution $\mathrm{pH}$ on the sorption of $\mathrm{Fe}(\mathrm{III})$ ions.

Table 1. The influence of the medium $\mathrm{pH}$ on the sorption of $\mathrm{Fe}(\mathrm{III})$ ions

\begin{tabular}{|c|c|c|c|c|c|c|c|c|c|c|c|}
\hline $\mathrm{pH}$ & 1 & 2 & 3 & 4 & 5 & 6 & 7 & 8 & 9 & 10 & 11 \\
\hline $\begin{array}{c}\mathrm{SC}, \\
\mathrm{mg} / \mathrm{g}\end{array}$ & 1.8 & 2.4 & 3.3 & 5.4 & 7 & 7.2 & 5.4 & 4.5 & 2.7 & 2.1 & 1.5 \\
\hline $\begin{array}{c}R, \\
\%\end{array}$ & 23 & 31 & 43 & 69 & 89 & 90.7 & 71 & 63.7 & 34.7 & 26.6 & 19 \\
\hline
\end{tabular}

As can be seen from Figure 2, an increase in the $\mathrm{pH}$ of the solution from 1 to 6 led to an increase in the $R$ value from 23 to $90.7 \%$, and a further increase in the $\mathrm{pH}$ of the solution from 6 to 11 resulted in a decrease in $\mathrm{R}$ from 90.7 to $19 \%$.

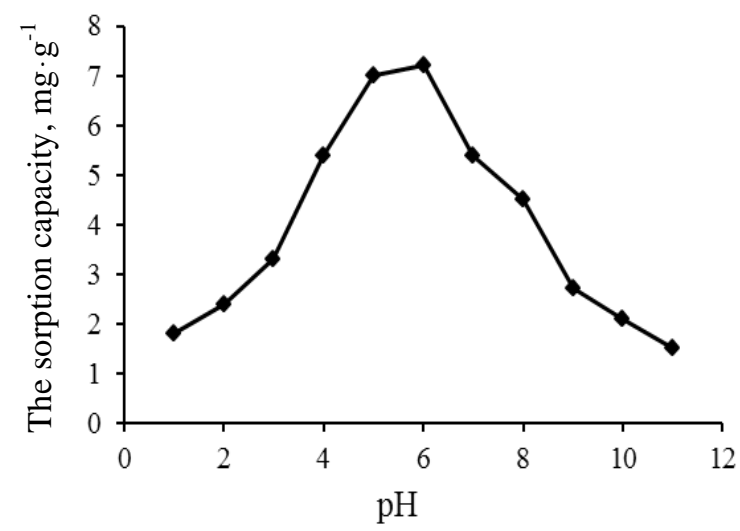

Fig. 2. The effect of the $\mathrm{pH}$ of the medium on the sorption of $\mathrm{Fe}(\mathrm{III})$ ions.

The highest values of removal efficiency were obtained in weakly acidic solutions $(\mathrm{pH}$ 6). This is due to the fact that at low $\mathrm{pH}$ values $(\mathrm{pH}<3)$ the functional groups of the sorbent are protonated [10].
The removal efficiency decreases at high $\mathrm{pH}$ values due to the abundance of $\mathrm{OH}-$ and/or due to ion repulsion between negatively charged sorbent functional groups and anionic iron salt molecules.

As a result, a further initial $\mathrm{pH}$ of 6.0 was chosen for further sorption experiments.

\section{Effect of sorbent mass}

Table 2 and Figure 3 show the effect of sorbent weight on the sorption capacity.

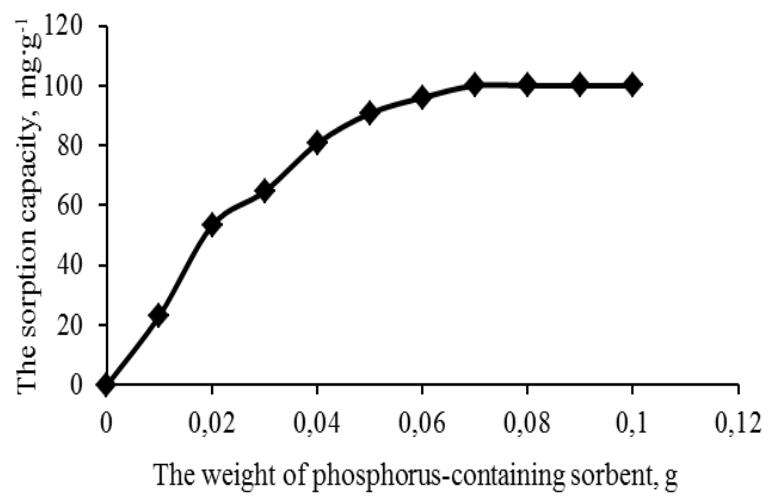

Fig. 3. Influence of the weight of phosphoruscontaining sorbent on the sorption of Fe(III) ions.

As can be seen, the value of the degree increases with increasing of sorbent mass to $0.06 \mathrm{~g}$ (corresponding to $96 \%$ of the initial amount of $\mathrm{Fe}$ (III) ions sorbed on the phosphorus-containing sorbent). The increase in the degree of sorption can be associated with an increase in the number of active functional groups associated with the presence of a large sorption surface.

\section{Fe(III)}

The effect of the initial concentration of

The initial concentration of sorbates is the main factor in sorption processes, since it affects the ion distribution between the solid and liquid phases $[12,13]$. The result of this study is shown in Table 3 and is shown in Figure 4.

The maximum value of the sorption degree is observed at a concentration $1.5 \cdot 10^{-3} \mathrm{M}$ $(90.7 \%)$. The degree of sorption decreases with increasing initial concentration of $\mathrm{Fe}$ (III) ions.

Table 2. Influence of the weight of the phosphorus-containing sorbent on the sorption of $\mathrm{Fe}(\mathrm{III})$

\begin{tabular}{|c|c|c|c|c|c|c|c|c|c|c|}
\hline The weight of sorbent, $\mathrm{g}$ & 0.01 & 0.02 & 0.03 & 0.04 & 0.05 & 0.06 & 0.07 & 0.08 & 0.09 & 0.1 \\
\hline $\mathrm{SC}, \mathrm{mg} / \mathrm{g}$ & 1.8 & 3 & 5.2 & 6 & 7.2 & 7.8 & 8 & 8 & 8 & 8 \\
\hline$R, \%$ & 23.3 & 53.3 & 64.7 & 80.7 & 90.7 & 96 & 100 & 100 & 100 & 100 \\
\hline
\end{tabular}


This indicates that the phosphorus-containing sorbent has a limited number of active sites for sorption, and at lower concentrations, almost all Fe(III) ions are sorbed. However, an increase in the initial concentration of $\mathrm{Fe}$ (III) ions leads to a rapid saturation of the sorbent surface.

\section{The effect of contact time}

Experiments have shown that the sorption of $\mathrm{Fe}(\mathrm{III})$ ions occurs rapidly in the first 8 minutes and becomes slower near equilibrium.
The results of the experiment are presented in Table 4. Figure 5 shows the effect of the contact time on the sorption of $\mathrm{Fe}(\mathrm{III})$ ions.

\section{The effect of temperature}

With an increase in temperature from 25 to $50^{\circ} \mathrm{C}$, the degree of sorption increases if, at $25^{\circ} \mathrm{C}$, equilibrium is reached after 70 minutes, then at $35^{\circ} \mathrm{C}$ it is established after $65 \mathrm{~min}$, and at $50^{\circ} \mathrm{C}-$ after 55 minutes. This can be seen from the Table 5 and Figure 6.

Table 3. Effect of initial concentration of $\mathrm{Fe}(\mathrm{III})$ ions on the sorption

\begin{tabular}{|c|c|c|c|c|c|c|}
\hline $\mathrm{C}_{0}, \mathrm{M}$ & $0.9 \cdot 10^{-3}$ & $1.1 \cdot 10^{-3}$ & $1.5 \cdot 10^{-3}$ & $1.7 \cdot 10^{-3}$ & $2.2 \cdot 10^{-3}$ & $2.6 \cdot 10^{-3}$ \\
\hline $\mathrm{SC}, \mathrm{mg} / \mathrm{g}$ & 1.2 & 2.1 & 7.2 & 6.8 & 4.7 & 3.8 \\
\hline$R, \%$ & 22.2 & 36.4 & 90.7 & 76.5 & 41 & 26.9 \\
\hline
\end{tabular}

Table 4. Effect of contact time on the sorption of Fe(III) ions

\begin{tabular}{|c|c|c|c|c|c|c|c|c|c|c|c|c|c|}
\hline The contact time, $t, \min$ & 3 & 8 & 15 & 20 & 25 & 30 & 35 & 40 & 45 & 50 & 55 & 60 & 65 \\
\hline $\mathrm{SC}, \mathrm{mg} / \mathrm{g}^{-1}$ & 2.1 & 3 & 3.6 & 3.9 & 4.2 & 4.5 & 4.8 & 5.3 & 5.7 & 6 & 6.3 & 6.9 & 7.8 \\
\hline$R, \%$ & 27.3 & 42.7 & 46.7 & 48.7 & 53.3 & 56 & 60 & 66.7 & 71.3 & 75.3 & 78.7 & 86.7 & 96 \\
\hline
\end{tabular}

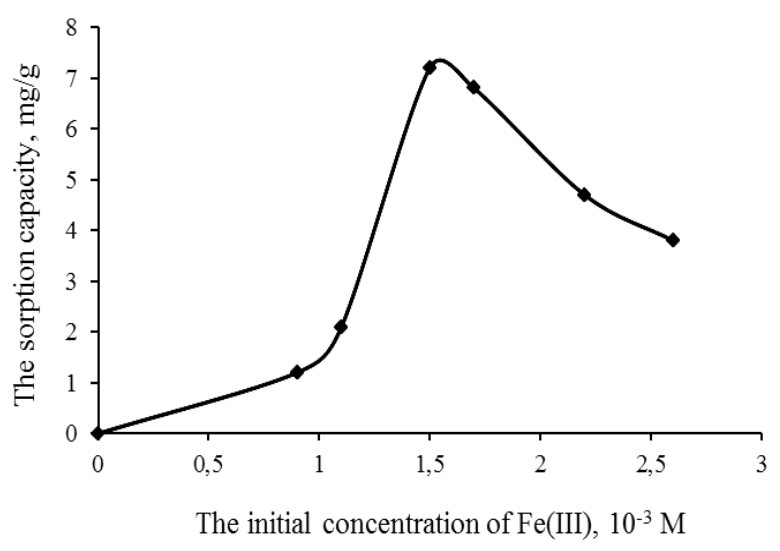

Fig. 4. Influence of the initial concentration of $\mathrm{Fe}(\mathrm{III})$ ions on the sorption.

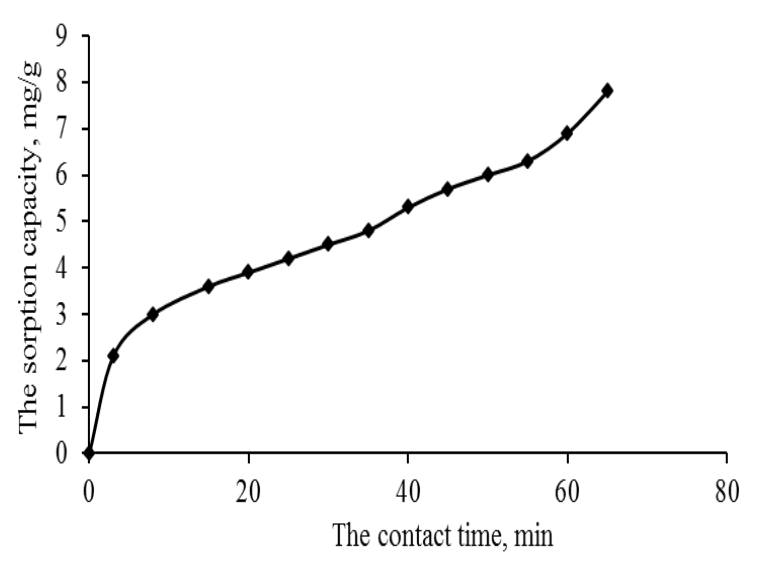

Fig. 5. The effect of contact time on the sorption of $\mathrm{Fe}(\mathrm{III})$ ions.

Table 5. The effect of temperature on the sorption of Fe(III) ions

\begin{tabular}{|c|c|c|c|c|c|c|}
\hline \multirow{2}{*}{$\begin{array}{c}\text { The contact time, } \\
t, \text { min }\end{array}$} & \multicolumn{2}{|c|}{$25^{\circ} \mathrm{C}$} & \multicolumn{2}{|c|}{$35^{0} \mathrm{C}$} & \multicolumn{2}{|c|}{$50^{\circ} \mathrm{C}$} \\
\hline & $\mathrm{SC}, \mathrm{mg} / \mathrm{g}$ & $R, \%$ & $\mathrm{SC}, \mathrm{mg} / \mathrm{g}$ & $R, \%$ & $\mathrm{SC}, \mathrm{mg} / \mathrm{g}$ & $R, \%$ \\
\hline 5 & 2.1 & 27.3 & 2.4 & 31.3 & 5.4 & 65.3 \\
\hline 10 & 3 & 42.7 & 3 & 48.7 & 5.7 & 73.3 \\
\hline 15 & 3.6 & 46.7 & 3.9 & 50 & 6 & 77.3 \\
\hline 20 & 3.9 & 48.7 & 4.2 & 52 & 6.3 & 78.7 \\
\hline 25 & 4.2 & 53.3 & 4.5 & 56 & 6.5 & 80.7 \\
\hline 30 & 4.5 & 56 & 4.8 & 62 & 6.6 & 82 \\
\hline 35 & 4.8 & 60 & 5.1 & 62 & 6.7 & 82.7 \\
\hline 40 & 5.3 & 66.7 & 5.7 & 71.3 & 6.9 & 84.7 \\
\hline 45 & 5.7 & 71.3 & 6 & 77.3 & 7.5 & 92.7 \\
\hline 50 & 6 & 75.3 & 6.9 & 84.7 & 7.8 & 98 \\
\hline 55 & 6.3 & 78.7 & 7.5 & 92.7 & 8 & 100 \\
\hline 60 & 6.9 & 86.7 & 7.8 & 98 & & \\
\hline 65 & 7.8 & 96 & 8 & 100 & & \\
\hline 70 & 8 & 100 & & & & \\
\hline
\end{tabular}




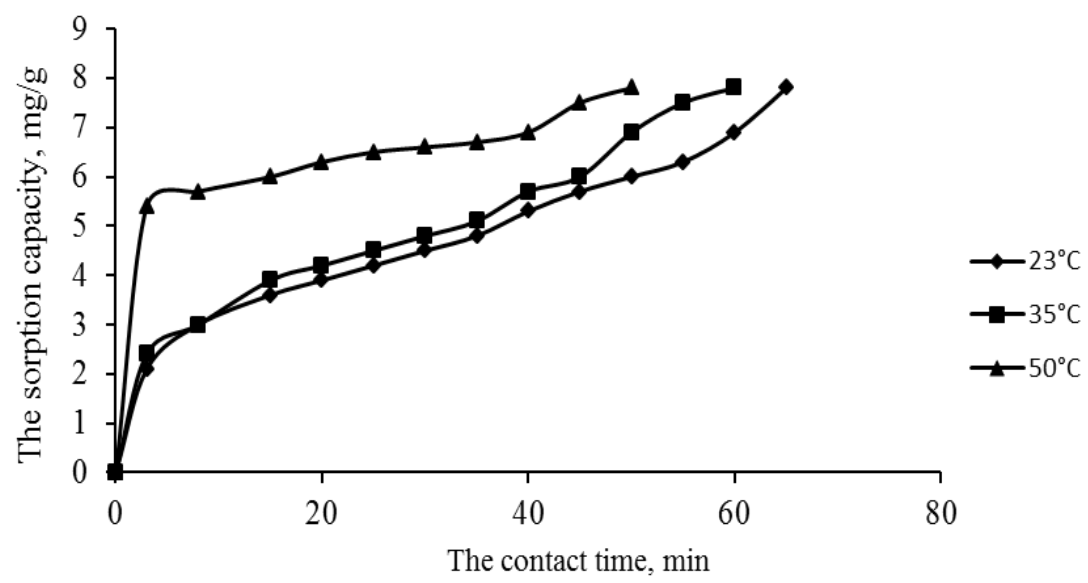

Fig. 6. Effect of temperature on the sorption of Fe(III) ions.

This result can be associated with an increase in the mobility of $\mathrm{Fe}$ (III) ions and an increase in the number of active sites on the surface of the sorbent. On the other hand, in nature, sorption of $\mathrm{Fe}$ (III) ions on a phosphoruscontaining sorbent is an endothermic process and can include chemical sorption. The endothermic nature of the sorption of pollutants has also been reported in other studies of our scientists, namely: the sorption of $\mathrm{Pb}^{2+}$ on a cellulose-based sorbent, the adsorption of $\mathrm{Pb}^{2+}$ on phosphatemodified kaolinite clay, the sorption of $\mathrm{Cu}^{2+}$ on a wood fern and the adsorption of a water-soluble dye on a functionalized resin [14-16].

\section{Adsorption isotherms}

Adsorption isotherms define the equilibrium relationship between adsorbent and adsorbate. In other words, the adsorption isotherms serve to describe how the adsorbed molecules interact with adsorbents when the process approaches equilibrium. The results obtained in this study were analyzed using the Langmuir, Freundlich and Dubinin-Radushkevich isotherm equations.

\section{Langmuir isotherm}

The Langmuir model is used to determine the homogeneity of the adsorption process. According to this model, the adsorbent's surface is homogeneous, each active site on the adsorbent's surface has the ability to sorb only one adsorbate molecule, and there is no interaction between the adsorbed molecules. In addition, in terms of energy, the active sites are equivalent to each other. The linear Langmuir isotherm equation is [17]:

$$
\frac{C_{\mathrm{e}}}{q_{\mathrm{e}}}=\frac{1}{q_{\max } K_{\mathrm{L}}}+\frac{C_{\mathrm{e}}}{q_{\max }}
$$

where $C_{\mathrm{e}}$ is the concentration of the iron remaining in the solution at equilibrium $(\mathrm{mg} / \mathrm{L})$ and $q_{e}$ is the amount of iron adsorbed at equilibrium $(\mathrm{mg} / \mathrm{g})$. The $q_{\max }$ constant is the adsorbent's maximum monolayer adsorption capacity $(\mathrm{mg} / \mathrm{g})$ and $K_{\mathrm{L}}$ is the adsorption constant $(\mathrm{L} / \mathrm{mg}$ ) and is related to the free energy of adsorption.

Linear plots of $C_{\mathrm{e}} / q_{\mathrm{e}}$ versus $C_{\mathrm{e}}$ showed that the iron adsorption on the phosphorcontaining sorbent followed the Langmuir isotherm. The values of the $q_{\max }$ and $K_{\mathrm{L}}$ were calculated from the slope and intercept of the plot, respectively.

The Langmuir isotherm's essential characteristics may be described through $R_{\mathrm{L}}$, a dimensionless constant separation factor or equilibrium parameter. $R_{\mathrm{L}}$ may be represented as [18]:

$$
R_{\mathrm{L}}=\frac{1}{1+K_{\mathrm{L}} C_{0}},
$$

where $K_{\mathrm{L}}\left(\mathrm{L} / \mathrm{mg}^{-1}\right)$ refers to the Langmuir constant and $C_{0}$ is the adsorbate's initial concentration $\left(\mathrm{mg} / \mathrm{L}^{-1}\right)$. The $R_{\mathrm{L}}$ value indicates the adsorption nature to be either unfavorable $\left(R_{\mathrm{L}}>1\right)$, linear $\left(R_{\mathrm{L}}=1\right)$, favorable $\left(0<R_{\mathrm{L}}<1\right)$, or irreversible $\left(R_{\mathrm{L}}=0\right)$.

\section{Freundlich isotherm}

The Fteundlich isotherm model involves heterogeneous surface adsorption sites that have different adsorption energies and provides no information about the monolayer adsorption 
capacity. The linear form of the Freundlich isotherm model equation is [19]:

$$
\ln q_{\mathrm{e}}=\ln K_{\mathrm{F}}+\frac{1}{n} \ln C_{\mathrm{e}},
$$

where $K_{\mathrm{F}}(\mathrm{mg} / \mathrm{g})$ and $n$ are the Freundlich isotherm constants related to adsorption capacity and adsorption intensity, respectively. The value of $1 / n$ is the degree of heterogeneity of phosphorcontaining sorbent. The linear plots of $\ln q_{e}$ versus $\ln C_{e}$ show that the adsorption of iron on phosphor-containing sorbent follows the Freundlich isotherm. The values of Freundlich constants, that is, $K_{F}$ and $1 / n$, were calculated from the intercept and slope of the linear plot, respectively.

\section{Dublin-Radushkevich isotherm}

The Dublin-Radushkevich (D-R) isotherm was selected to assess the adsorbent's porosity. The linear form of the $\mathrm{D}-\mathrm{R}$ isotherm equation is [20]:

$$
\ln q_{\mathrm{e}}=\ln q_{\mathrm{s}}-K_{\mathrm{D}-\mathrm{R}} \varepsilon^{2},
$$

where $q_{s}$ is the theoretical saturation capacity $(\mathrm{mg} / \mathrm{g}), K_{\mathrm{D}-\mathrm{R}}$ is the D-R isotherm constant related to the mean free energy of adsorption per mole of the adsorbate $\left(\mathrm{mol}^{2} / \mathrm{kJ}^{2}\right)$, and $\varepsilon$ is the Polanyi potential that is related to the equilibrium concentration as follows:

$$
\varepsilon=R T \ln \left(1+\frac{1}{C_{\mathrm{e}}}\right),
$$

where $R\left(8.314 \mathrm{~J} \mathrm{~mol}^{-1} \mathrm{~K}^{-1}\right)$ is the gas constant and $T(\mathrm{~K})$ is the absolute temperature. The linear plots of $\ln q_{\mathrm{e}}$ versus $\varepsilon^{2}$ show that the adsorption of iron on the sorbent follows the D-R isotherm (plot not shown). The values of $q_{\mathrm{s}}$ and $K_{\mathrm{D}-\mathrm{R}}$ were calculated from the intercept and slope using linear regression.

The obtained different isotherm parameters are shown in Table 6.

\begin{tabular}{|c|c|c|c|c|}
\hline \multicolumn{5}{|c|}{ Langmuir } \\
\hline $\begin{array}{l}\text { Maximum adsorption ca- } \\
\text { pacity }\left(q_{\max }, \mathrm{mg} / \mathrm{g}\right)\end{array}$ & \multicolumn{2}{|c|}{$\begin{array}{l}\text { Langmuir adsorption } \\
\text { constant }\left(K_{\mathrm{L}}, \mathrm{L} / \mathrm{mg}^{-1}\right)\end{array}$} & Separation factor $\left(\mathrm{R}_{\mathrm{L}}\right)$ & Correlation coefficient $\left(r^{2}\right)$ \\
\hline 2.34 & \multicolumn{2}{|c|}{0.26} & $0-1$ & 0.826 \\
\hline \multicolumn{5}{|c|}{ Freundlich } \\
\hline \multicolumn{2}{|c|}{$\begin{array}{l}\text { Freundlich isotherm constant } \\
\left(K_{\mathrm{F}}, \mathrm{mg} / \mathrm{g}\right)\end{array}$} & \multicolumn{2}{|c|}{ Degree of heterogeneity $(1 / n)$} & Correlation coefficient $\left(r^{2}\right)$ \\
\hline \multicolumn{2}{|c|}{10.7} & \multicolumn{2}{|c|}{-0.3856} & 0.6534 \\
\hline \multicolumn{5}{|c|}{ Dubinin-Radushkevich } \\
\hline \multicolumn{2}{|c|}{$\begin{array}{l}\text { Theoretical saturation capacity } \\
\qquad\left(q_{\mathrm{s}}, \mathrm{mg} / \mathrm{g}\right)\end{array}$} & \multicolumn{2}{|c|}{$\begin{array}{l}\text { Dubinin-Radushkevich isotherm } \\
\text { constant }\left(K_{\mathrm{D}-\mathrm{R}}, \mathrm{mol}^{2} / \mathrm{KJ}^{-2}\right)\end{array}$} & Correlation coefficient $\left(r^{2}\right)$ \\
\hline \multicolumn{2}{|c|}{4.4} & \multicolumn{2}{|c|}{$3 \cdot 10^{-7}$} & 0.902 \\
\hline
\end{tabular}

Table 6. Langmuir, Freundlich and Dubinin-Radushkevich isotherm parameters for the adsorption of iron on the phosphorus-containing polymeric sorbent on the basis of butadiene-styrene rubber

\section{Conclusions}

In the present study the sorption capacity of the phosphor-containing sorbent synthesized by oxidative chlorophosphorylation of butadiene-styrene rubber followed by hydrolysis with respect to $\mathrm{Fe}$ (III) ions was studied, determining the influence of various parameters such as the $\mathrm{pH}$ of the solution, the initial concentration of the salt $\mathrm{FeCl}_{3} \cdot 6 \mathrm{H}_{2} \mathrm{O}$, the sorbent mass, phase contact time and temperature. Experimental results have shown that a phosphorus-containing sorbent based on butadiene-styrene rubber can be successfully used to extract Fe(III) ions from aqueous solutions.

\section{References}

1. Tataeva S.D., Akhmedov S.A., Gamzaeva U.G. Sorbtciia medi(II) na anionitakh s immobilizovannoi formazanovoi gruppirovkoi // Sorbtcionnye i khromatograficheskie protcessy. 2005. T. 5. Vyp. 5. S. 696-703.

2. Demirbas A. Agricultural based activated carbons for the removal of dyes from aqueous solutions // J. Hazard. Mater. 2009. V. 167. P. 1-9.

3. Gupta V., Suhas K. Application of low-cost adsorbents for dye removal // Journal of Environ. Managem. 2009. V. 90. P. 2313-2342.

4. Panić V., Šešlija S.I., Nešić A.R. Adsorption of azo dyes on polymer materials // Hem. Ind. 2013. V. 67. P. 881-899. 
5. Magerramov A.M., Alosmanov R.M., Melikova A.Ia. Fosfokhlorirovanie polibutadiena fosfor(III)khloridom v prisutstvii kisloroda // Izv. vuzov. Himiia i him. tekhnologiia. 2003. T. 46. № 6. C. 25-27.

6. Pat. № 0108. Az. R. Fəza quruluşlu polibutadien fosfon turşusunun [2,3-dimetil-1-fenil-5-pirazalon] monoimidi uran (VI)-nın sorbenti kimi / Ozizov A., Rəhimov R., Alosmanov R. 2003

7. Harris D.C. Quantitative Chemical Analysis. New York: W.H. Free man. 2007. P. 51-64.

8. Pollard J.H., Handbook of Numerical and Statistical Techniques. Cambridge University Press, Cambridge. 1977. P. 374.

9. Alosmanov R.M., Azizov A.A., Magerramov A.M. IAMR-spektroskopicheskoe issledovanie fosforsoderzhashchego polimernogo sorbenta // Rossiiskii Zhurn. obshch. himii. 2011. T. 81. № 7. C. 23-24.

10. Alosmanov R.M., Azizov A.A., Maharramov A.M. acid base sorption properties of phosphorus containing polymeric sorbent // Mater. Res. Innovations. 2010. V. 14. No 5. P. 414-418.

11. Saladadze K.M., Kopilova-Valova V.D. Kompleksnye ionnye teploobmenniki. M: Nauka, 1980. C. 336.

12. Ramazanov A.Sh., Esmail G.K. Sorbtcionnoe koncentrirovanie ionov medi, tcinka, kadmiia i svintca iz vodny`kh rastvorov prirodnoi glinoi // Vest. Dagestanskogo gos. Un. 2014. Vyp. 1. C. 179-183.
13. Eremin O.V., E`pova E.S., Rusal O.S. Sorbtciia ionov tcinka iz vodnykh rastvorov prirodnym clinoptilovlitovym tufom // Uspehi sovremennogo estestvoznaniia. 2015. № 10. C. 86-91.

14. Ho Y.S., Wase D.A., Forster C.F. Removal of lead ions from aqueous solution using sphagnum moss peat as adsorbent // Water SA. 1996. V. 22. P. 219-224.

15. Unuabonah E.I., Adebowale K.O. Kinetic and thermodynamic studies of the adsorption of lead(II) ions onto phosphate-modified kaolinite clay // J. Hazard. Mater. 2007. V. 144. P. 386395.

16. Ho Y.S., Huang C.T., Huang H.W. Equilibrium sorption izotherm for metal ions on tree fern // Process Biochem. 2002. V. 37. P. 1421-1430.

17. Langmuir I. The adsorption of gases on plane surfaces of glass, mica and platinum // Journal of the American Chemical Society. 1918. P. 1361.

18. Hall K.R., L.C.Eagleton, A.Acrivos and T.Vermeulen. Pore- and solid-diffusion kinetics in fixed-bed adsorption under constant-pattern conditions // Instrumental\&Engineering Chemistry Fundamentals. 1996. P. 212.

19. Freundlich H.M.F. Über die adsorption in lösungen Z. // Phys. Chemi. 1906. P. 385-470.

20. Dublin M.M., Radushkevich L.V. Equation of the characteristic curve of activated charcoal // Proceeding of the Union of Soviet Socialist Republics Academy of Sciences of the USSR. Phys. Chem. Section. 1947. V. 55. P. 331-337.

\section{Fe(III) İONLARIN ÇIXARILMASI MəQSəDİ İLə BUTADİEN-STIROL KAUÇUK ӘSASINDA FOSFORTəRKİBLİ SORBENTIN ISTTIFADӘSI}

\section{E.S.Kərimova, A.Ә.Әzizov, R.M.Alosmanov}

Fe(III) ionlarını sudan çıxarmaq üçün butadien-stirol kauçukun əsasında fosfortərkibli sorbent istifadə edilmişdir. Sorbsiyanın məhlulun pH göstəricisindən, metal ionlarının ilkin konsentrasiyasından, sorbent kütləsindən, faza təmas vaxtından və temperaturdan asılılı̆̆ının öyrənilməsi məqsədi ilə tədqiqatlar aparılıb.

Açar sözlor: çlxarmaq, polimer sorbenti, sorbsiya, dəmir.

\section{УДАЛЕНИЕ ИОНОВ Fе(III) С ИСПОЛЬЗОВАНИЕМ ФОСФОРСОДЕРЖАЩЕГО СОРБЕНТА НА ОСНОВЕ БУТАДИЕН-СТИРОЛЬНОГО КАУЧУКА}

\section{Э.С.Керимова, А.А.Азизов, Р.М.Алосманов}

Фосфорсодержащий полимерный сорбент на основе бутадиен-стирольного каучука использовали для удаления ионов $\mathrm{Fe}(\mathrm{III})$ из воды. Проводили исследования по изучению сорбционных характеристик, определяя влияния различных параметров, таких как рН раствора, начальная концентрация ионов металла, масса сорбента, время контакта фаз и температура.

Ключевые слова: удаление, полимерный сорбент, сорбция, железо. 